\title{
Comparisons of the queen volatile compounds of instrumentally inseminated versus naturally mated honey bee (Apis mellifera) queens*
}

\author{
Ming Hua HUANG ${ }^{1}$, Gloria DeGrandi-HoFfMAN ${ }^{2}$, Blaise LeBlanc ${ }^{2}$ \\ ${ }^{1}$ Department of Entomology, University of Arizona, Forbes 410, PO Box 2100: (36), Tucson, \\ AZ 85721-0036, USA \\ ${ }^{2}$ Carl Hayden Bee Research Center, USDA-ARS, 2000 East Allen Road, Tucson, AZ 85719, USA
}

Received 11 July 2008 - Revised 22 November 2008 - Accepted 12 December 2008

\begin{abstract}
Instrumental insemination is an attractive alternative to natural mating because specific genetic crosses can be made, thus producing colonies with desired traits. However, there are conflicting reports on the quality and acceptance of instrumentally inseminated (II) queens compared to naturally mated (NM) queens. One factor that affects acceptance and retention of queens is the volatile compounds they produce. Our study compared volatile chemicals from virgin and mated honey bee queens that were either NM or II. The volatile compounds from virgin queens differed from those of mated egg-laying queens. Virgin queens produced greater relative amounts of the volatile compounds we detected (including 2-phenylethanol, noctanal, and n-decanal) with the exception of $\mathrm{E}-\beta$-ocimene, which was higher in mated laying queens. II and NM queens did not differ in type or relative amounts of volatile compounds. The similarities between II and NM queens indicate that the physiological changes that happen after mating and egg laying occur regardless of the mating method.
\end{abstract}

E- $\beta$-ocimene / queen acceptance / n-decanal / n-octanal / 2-phenylethanol

\section{INTRODUCTION}

In a honey bee colony, the production of pheromones by the queen is important for advertising her presence to the workers (Slessor et al., 1988; Hoover et al., 2003; Keeling et al., 2003). Compounds such as queen mandibular pheromone (QMP) help stimulate retinue behavior and play a role in inhibiting the activation and the development of worker ovaries. All components of QMP have been identified thus far as nonvolatile compounds that are spread via allogrooming (Naumann et al., 1992; KatzavGovansky et al., 2004). However, there also are queen specific volatile compounds such

Corresponding author: M.H. Huang,

mhuang@ag.arizona.edu

* Manuscript editor: Peter Rosenkranz as $\mathrm{E}-\beta$-ocimene and 2-phenylethanol that are associated with the queen's egg laying state (Gilley et al., 2006). Contact pheromones and compounds emitted as volatiles from queens differ depending upon mating and egg laying status (Pankiw et al., 1996; Wossler et al., 2006). Whether the change in the amount and composition occurs due to mating or because the queen is laying eggs is unclear.

Queens mate naturally by taking mating flights and copulating with drones. Queens also can be instrumentally inseminated (Laidlaw, 1992). Instrumental insemination has become an attractive alternative to natural mating because specific genetic crosses can be made, thus producing colonies with desired traits such as Varroa mite resistance (Harbo and Harris, 1999), pollen hoarding (Page and Fondrk, 1995) and hygienic behaviors (Rothenbuhler, 1964). 
Despite the potential benefits of instrumental insemination, the performance of instrumentally inseminated (II) queens as compared to naturally mated (NM) queens has been debated. Some recent studies have shown that II queens have more consistent and greater quantity of spermatozoa in the spermatheca, begin laying eggs earlier, and live as long as NM queens (see Cobey, 2007). Also, II queens tend to establish colonies that have equal or greater honey production and brood production as compared to colonies of NM queens. However, there has been concern that the pheromone development [e.g., queen mandibular pheromone (QMP)] may be delayed in II queens compared with NM queens, thus affecting queen acceptance (Cobey, 2007). Secretions from the tergal gland found on the dorsal surface of the abdomen also play a role in interactions between the queen and her workers. A mixture of various tergal gland secretions (TGS) in addition to QMP advertises her mating status to her workers and sustains worker retinue behavior (Slessor et al., 1988). The initiation of TGS production in II queens tend to be delayed by approximately 40 days post emergence due to the lack of mating flights (Smith et al., 1993).

In addition to the non-volatile pheromones above, honey bee queens also produce specific volatile compounds that may differ between II and NM queens (Gilley et al., 2006). The relative amounts and composition of volatile compounds can affect queen acceptance (DeGrandi-Hoffman et al., 2007). Here, we perform a quantitative study that compares the volatile chemical profile of II queens with NM queens from the virgin queen stage to colony establishment. Because sampling for volatile compounds using solidphase microextraction devices (SPME) is nondestructive to the organism, we can examine changes in the composition of the profile in the same queen. Ontogenetic shifts in compounds associated with natural mating can be compared with those occurring after instrumental insemination. Differences that might exist after the queens begin to lay also can be identified. The purpose of our study was to determine if there were differences in the volatile chemical profiles of naturally mated and instrumentally inseminated queens from their time of emergence until they became established laying queens in colonies.

\section{MATERIALS AND METHODS}

\subsection{Queen rearing and mating}

Our studies were performed at the Carl Hayden Bee Laboratory in Tucson, Arizona, USA during the summer of 2006. All queens used in this study were grafted from larvae produced by a single European queen (Apis mellifera ligustica) purchased from Big Island Queens in Captain Cook, Hawaii (Laidlaw, 1979). Queens were selected at random while still sealed in their cells and placed in queenless colonies that contained adult workers and two frames of brood, honey, and pollen. Colonies housing queens to be instrumentally inseminated had queen excluders fastened onto the entrances to prevent queens from leaving the hive to mate. Entrances of hives for NM queens were kept open. II queens were marked on the thorax with blue paint and NM queens were marked with yellow paint. All colonies were checked every other day for signs of egg laying and queen rejection.

Queens were instrumentally inseminated using the techniques described in Laidlaw (1979). Semen was collected from drones captured while returning to their colonies. Multiple colonies were used to collect drones so that the queens would be inseminated with semen from different patrilines ( $\sim 7$ drones and $5 \mu \mathrm{L}$ of semen per queen). Instrumentally inseminated queens were anesthetized twice with $\mathrm{CO}_{2}$; once just before insemination and a second time approximately 24 to 48 hours after insemination (Mackensen, 1947).

\subsection{Sampling volatile compounds from queens}

The chemical profiles of NM and II queens were sampled and compared during three different periods. The first sampling occurred one to two days after the queens' emergence. The second was when queens were 7-8 days old and were still virgins. During the third sampling period, all queens were mated and laying eggs in colonies for at least a month (i.e., established queens).

Volatile compounds emanating from queens were sampled with a SPME device containing a $65 \mu \mathrm{m}$ polydimethylsiloxane divinylbenzene fiber 
(Supelco SPME fiber 57326U). The SPME fiber was conditioned by placing it in the injection port of a Varian CP-3800 GC/Saturn 2200 MS system overnight at a temperature of $250{ }^{\circ} \mathrm{C}$ and then again for 30 min before use. A blank SPME fiber was run before any insect volatiles were adsorbed at the beginning and end of the day. Blanks were run consecutively until there was no background signal.

Volatiles were collected by placing a single queen in clean $50 \mathrm{~mL}$ glass Erlenmeyer flasks shaded from the lighted room with aluminium foil. The flasks were fitted with a wire cage insert that surrounded the SPME fiber to prevent physical contact between the bee and the fiber during sampling. A new flask and fitted wire cage were used for each individual queen sampled to prevent contamination of volatiles. Volatiles were collected for $10 \mathrm{~min}$ at absolute humidity fluctuating between $6 \mathrm{~g} / \mathrm{m}^{3}$ and $11 \mathrm{~g} / \mathrm{m}^{3}$ and temperatures between $23^{\circ} \mathrm{C}$ and $27^{\circ} \mathrm{C}$. The fiber was immediately injected into the GC/MS and desorbed for 3 minutes at $240{ }^{\circ} \mathrm{C}$ in splitless mode. The compounds were separated on a Varian CP-3800 series GC, equipped with a solid phase micro-extraction modified injection port and a Varian Factor Four Capillary $(30 \mathrm{~m} \times 0.25 \mathrm{~mm}$ ID) column VF-1ms, Cat. \# CP8912 and with a Saturn $2200 \mathrm{MS}$ ion trap detector in the EI mode at 150 electron volts $(\mathrm{eV})$. Helium [ultra high purity (UHP)] was the carrier gas and was filtered though a gas purifier before the connection to the GC. The following programmed parameters were used: column temperature of $40{ }^{\circ} \mathrm{C}$ for $3 \mathrm{~min}$, then ramped to $250{ }^{\circ} \mathrm{C}$ at 15 degrees per minute, and helium at a constant flow rate of $1 \mathrm{~mL} / \mathrm{min}$. The MS was operated in EI mode at $150 \mathrm{eV}$ or in CI mode at $10 \mathrm{eV}$, using acetonitrile as the chemical ionization agent. GC/MS data were collected and processed using Saturn Workstation v. 5.52 software (Varian Analytical Instruments) [Gilley et al., 2006]. A NIST (version 1995) database was used to interpret the mass spectra and named compounds were positively identified by comparing their retention times with those of standards from purchased compounds, with the exception of n-decanal, which was prepared from the oxidation of 1-decanal using a modified method described in Vogel et al. (1989).

\subsection{Statistical analysis}

Relative amounts of Peaks 1, 4, 5, 6, 7, 8, 9, and 12 were compared between II and NM queens using separate repeated measures analysis of variance for each compound using queen type as the factor, date of sample as it relates to the state of the queen as the repeated measure, and an interaction term (queen type $\times$ state). Only peaks detected in at least $50 \%$ of the queens used during each sampling interval were included in the analysis.

\section{RESULTS}

Volatile compounds were sampled from 20 virgin queens. Of the 10 queens that were instrumentally inseminated, one queen escaped and was lost before we could sample her during the mated egg-laying state. A second II queen was not found again in the colony and was most likely killed shortly after introduction. Thus, we were neither able to sample her for volatiles during the virgin state nor the mated egg-laying state. All 10 of the queens selected for natural mating were accepted and laid eggs in their colonies.

\subsection{Volatile chemicals from queens}

Twelve peaks occurred in more than $50 \%$ of all queens used during at least one of the queen states that we sampled (Fig. 1). Peaks 1, 3, 4, $5,7,8,9$ and 12 were found in some queens in all states. Peaks 2, 6, 10 and 11 were detected only in virgin queens (peak 11 was detected in one II queen in very low relative amounts after she began laying). We detected two compounds previously identified by Gilley et al. (2006) as 2-phenylethanol (Peak-7) and E- $\beta$ ocimene (Peak-5) [see Fig. 2]. Peak-4 was identified as n-octanal. Peak 9 was the only compound detected in most queens regardless of state, and was identified as n-decanal. Peaks 2 and 3 were found in relatively low concentrations regardless of queen type and state. Peak 2 was identified to be n-heptanal while peak 3 was possibly $\beta$-pinene. Peaks 8 and 11 were long chain hydrocarbons but their exact identity could not be determined. Peaks 10 and 12 were also long chain hydrocarbons that were possibly an octadecene isomer and nondecane, respectively. Peaks 1 and 6 could not be definitively identified.

Relative amounts of all peaks that occurred in more than $50 \%$ of the queens (Peaks 2, 3, 


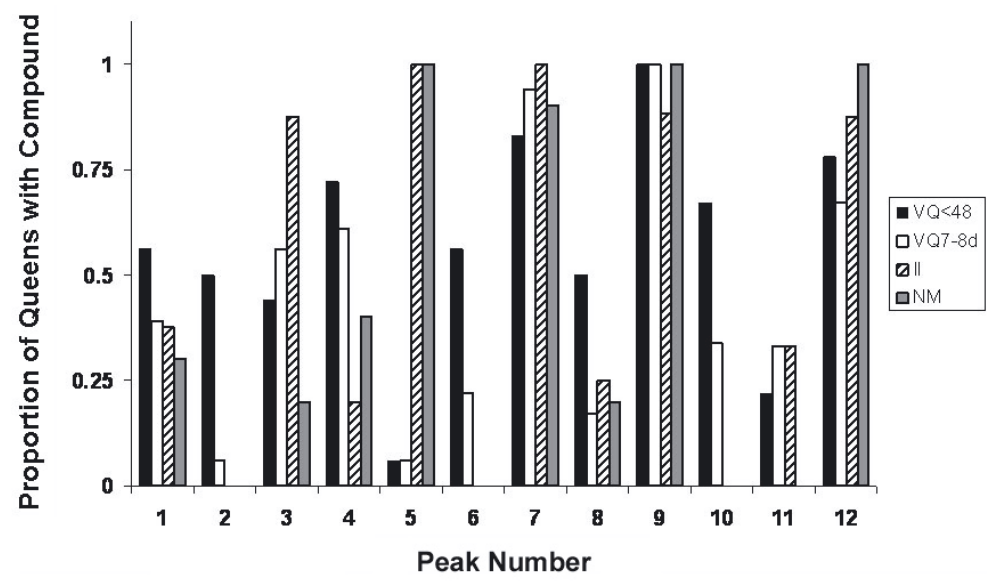

Figure 1. Proportion of virgin queens less than 48 hours old (VQ<48), 7-8 days old (VQ 7-8 d), instrumentally inseminated (II) and naturally mated (NM) queens that were established and laying eggs in colonies where volatile compounds were detected. The compounds are represented by peak numbers on a gas chromatogram.

Table I. Results from a repeated measures analysis of variance of average relative amounts of volatile compounds collected from live honey bee queens at three different developmental states (virgins $<48 \mathrm{~h}$ old, virgins 7-8 days old, and mated egg-laying queens). Each queen sampled was either open-mated $(n=10)$ or instrumentally inseminated ( $n=9$ for virgin queens and $n=8$ for egg-laying queens) [queen type]. Volatiles were analyzed using gas chromatography and mass spectroscopy. Compounds were either identified or characterized as peaks on a gas chromatogram. For all queen type data, $d . f .=1$; for all queen state data, d.f. $=2$; type $\times$ state, $d . f .=2$.

\begin{tabular}{lcccccc}
\hline Peak & \multicolumn{2}{c}{ Queen Type } & \multicolumn{2}{c}{ Queen State } & \multicolumn{2}{c}{ Type $\times$ State } \\
& F & $P$ & F & $P$ & F & $P$ \\
\hline 1 & 1.62 & 0.212 & 3.7 & 0.035 & 0.43 & 0.65 \\
4 (n-octanal) & 1.25 & 0.271 & 22.1 & $<0.0001$ & 1.21 & 0.31 \\
5 (E- $\beta$-ocimene) & 0.52 & 0.730 & 32.0 & $<0.0001$ & 0.55 & 0.58 \\
6 & 2.58 & 0.12 & 35.4 & $<0.0001$ & 2.88 & 0.07 \\
7 (2-phenylethanol) & 0.22 & 0.64 & 5.8 & 0.006 & 0.91 & 0.41 \\
8 (long chain hydrocarbon) & 0.20 & 0.66 & 12.3 & $<0.0001$ & 0.04 & 0.96 \\
9 (n-decanal) & 0.06 & 0.80 & 23.7 & $<0.0001$ & 0.03 & 0.97 \\
12 (long chain hydrocarbon) & 1.40 & 0.24 & 8.0 & 0.001 & 0.81 & 0.45 \\
\hline
\end{tabular}

and 11 were not included in the analysis) differed significantly depending upon the state of the queens (Tab. I). Virgin queens that were less than $48 \mathrm{hrs}$ old had relative amounts of peaks $4,6,9$ and 10 that were more than 10 times higher than in other states we sampled (Fig. 3).
E- $\beta$-ocimene was not detected in virgin queens with the exception of one queen that had very low levels. The compound was present in all mated queens. Relative amounts of E- $\beta$-ocimene differed among the sampling intervals, with the highest relative amounts occurring once queens were mated and laying 


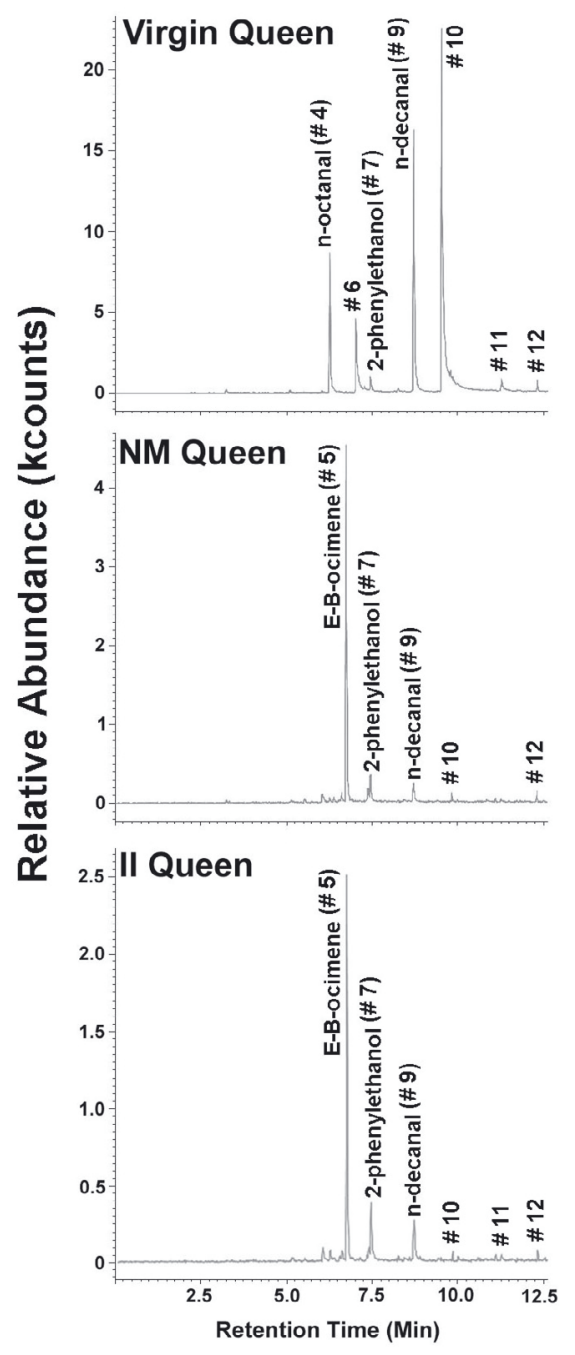

Figure 2. Sample chromatograms of volatile compounds from queens that were virgins, naturally mated (NM), or instrumentally inseminated (II). Definitive identities of peaks 6, 10, 11, and 12 were not made. Peaks 10, 11, and 12 are long chain hydrocarbons. More specifically, peak 10 is possibly an octadecene isomer while peak 12 is possibly nondecane.

$(F=32.03$, d.f. $=2, P<0.0001)$. Relative amounts of the compound did not differ between II and NM queens $(F=0.52, d . f .=1$, $P=0.73$ ) and were not affected by the interaction between the queen type and her state $(F=0.55, d . f .=2, P=0.58)$. Relative amounts of 2-phenylethanol also did not differ between NM and II queens $(F=0.22, d . f$. = $1, P=0.64)$. However, relative amounts of the compound differed depending on queen state $(F=5.82$, d.f. $=2, P=0.006)$. Higher relative amounts occurred prior to the queen mating and lower relative amounts after the queen was laying for several weeks. These differences in relative amounts of 2-phenylethanol between virgin and laying queens were not affected by the interaction between queen state and queen type $(F=0.91, d . f .=2, P=0.41)$.

\section{DISCUSSION}

The chemical profile of volatile compounds emanating from virgin queens was greater in relative amount and complexity than after the queens mated and were laying eggs. Queens produced higher relative amounts of seven compounds when they were virgins while producing only one dominant compound after they are mated (Fig. 3). The decreases in the relative amounts of volatile compounds occurred regardless of whether the queen was II or NM; both queen types had comparable volatile chemical signatures. Previously identified queen specific compounds, 2 -phenylethanol and $\mathrm{E}-\beta$-ocimene, were both detected. The highest relative amounts of 2phenylethanol were found in virgin queens. Quantities declined after queens mated (Gilley et al., 2006). We found similar reductions in the relative amounts of this compound suggesting that insemination (either instrumentally or through natural mating) followed by egg laying causes similar physiological changes that decrease the production and/or release of 2-phenylethanol. Similarly, relative amounts of $\mathrm{E}$ - $\beta$-ocimene are lowest in virgin queens and highest in queens that are laying. The process of ovary activation and egg laying appear to be related to E- $\beta$-ocimene production, and occur whether or not the queen has taken a mating flight.

Here, we show that the profile of volatile compounds collected from European honey bee queens differed greatly in presence and relative amounts depending upon whether the queen was a virgin or mated. Differences 


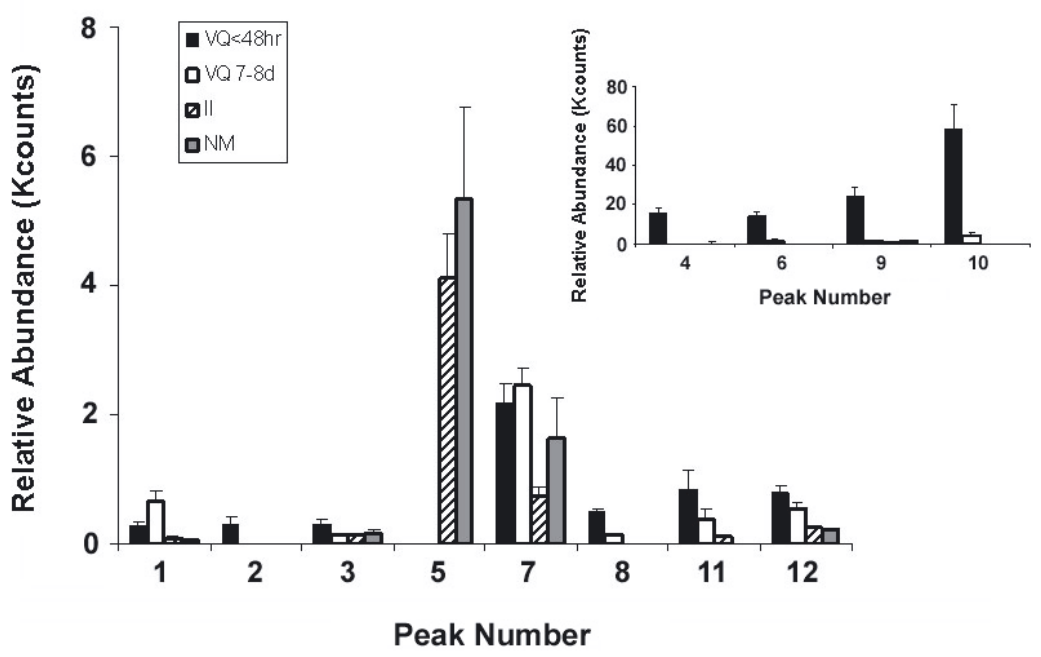

Figure 3. Relative amounts of 12 volatile compounds collected from virgin queens less than 48 hours old (VQ<48), 7-8 days old (VQ 7-8 d), instrumentally inseminated (II) and naturally mated (NM) queens. The compounds are represented by peak numbers on a gas chromatogram. Inset plot shows four compounds whose relative amounts were ten-fold higher than the other eight.

in pheromone production between virgin and mated queens has also been shown for other honey bee subspecies such as Apis mellifera carnica (Engels et al., 1997) and A. m. capensis (Wossler et al., 2006) as well as in some ant species such as Solenopsis invicta (Vargo, 1997, 1999) and Myrmica rubra (Brian, 1973). Compounds found in high relative amounts only in virgin queens less than 48 hrs old might be important during the honey bee queen reduction process. Honey bee workers rear many queens during the replacement process. The first queen to emerge usually becomes the new queen in the colony (Schneider and DeGrandi-Hoffman, 2002, 2003). However, multiple virgin queens can sometimes emerge simultaneously. In such cases, workers appear to influence the outcome of the potentially aggressive encounters between virgin queens using vibration signals directly on the dueling queens (Schneider and DeGrandiHoffman, 2003). Thus, workers ultimately decide as a group which queen they will allow to become the new queen in the colony (Tarpy and Gilley, 2004). It is unclear what mechanisms workers use to make their decisions, but perhaps the volatiles we detected in newly emerged virgin queens play a role.
The change in the presence and relative amounts of volatile compounds between virgin and mated queens is similar to what occurs in the production of the various components in queen mandibular pheromone (QMP). Overall QMP and its specific chemical components are present in much greater relative amounts in mated queens than virgin queens (Pankiw et al., 1996; Richard et al., 2007). Similarly, we found differences between virgin and mated queens. However, with the exception of $\mathrm{E}-\beta$-ocimene, the compounds were present in greater relative amounts when queens were virgins compared with after they were mated. The differences between virgin and mated queens in both non-volatile QMP and volatile chemical signals suggests an important biosynthetic change occurring after mating that provides signals to workers on the mating status of the queen through contact or volatile compounds. The shift in compounds being produced by mated queens might be triggered by ovary development and egg laying, the presence of sperm in the spermatheca, or possibly both. The requirement of an actual mating flight and copulation with drones does not appear to be necessary to induce the shift in the production of the compounds. 
We detected previously reported queen specific volatile compounds, but we also found ndecanal and n-octanal that are volatiles associated with workers (Torto et al., 2005). Both decanal and octanal are attractants for various insects including other Hymenoptera (Jumean et al., 2005). Octanal was detected in greatest relative amounts in virgin queens. However, a study by Becker et al. (2000) indicated that the compound probably is not an attractant for drones.

Our study demonstrates that volatile compounds, much like contact pheromones, change in composition and relative amount as honey bee queens develop from virgins to mated and egg-laying individuals. However, $\mathrm{NM}$ and II queens do not differ in the types or relative amounts of volatile compounds they produce, particularly in E-B-ocimene which is associated with queen acceptance (DeGrandi-Hoffman et al., 2007). Indeed, we confirm that the acceptance rate of II queens were comparable to that of NM queens. These results suggest that the physiological changes that occur when a queen begins to lay are not dependent on natural mating.

\section{ACKNOWLEDGEMENTS}

We thank Thomas Deeby for technical assistance in instrumentally inseminating the queens and Anna Dornhaus and Sue Cobey for their valuable suggestions and comments on earlier versions of this manuscript.

Comparaison des composants volatils de la reine d'abeilles (Apis mellifera) entre reines inséminées artificiellement et reines accouplées naturellement.

acceptation reine / n-decanal / n-octanal / 2phényléthanol / E- $\beta$-Ocimene

Zusammenfassung - Ein Vergleich von Königinnenduftstoffen zwischen instrumentell besamten und natürlich gepaarten Honigbienenköniginnen (Apis mellifera). Die instrumentelle Besamung von Honigbienenköniginnen ist eine attraktive Alternative $\mathrm{zu}$ natürlich gepaarten Königinnen, da auf spezielle Eigenschaften wie erhöhte Varroaresistenz, Pollensammelverhalten und Hygieneverhalten selektiert werden kann. Trotz dieser möglichen Vorteile wird nach wie vor diskutiert, ob das chemische Profil von instrumentell besamten Königinnen (II) sich von dem natürlich gepaarter Königinnen (NM) unterscheidet und dadurch deren Akzeptanz innerhalb des Bienenvolkes beeinflusst. Als erstes Ziel dieser Arbeit sollte untersucht werden, ob sich das chemische Profil (vor allem volatile Bestandteile) von unbegatteten Königinnen ändert, wenn sie sich zu begatteten Königinnen in Eilage entwickelt haben. Darüber hinaus analysierten wir, wie sich die Muster der abgegebenen Duftstoffe zwischen II- und NMKöniginnen unterscheiden. Wir besamten zufällig ausgewählte europäische Königinnen mit $5 \mu \mathrm{L}$ Samen von ca. 7 Drohnen aus unterschiedlichen Völkern. Danach hielten wir die II-Königinnen in einem weisellosen Bienenvolk mit Bienen, Brutwaben sowie Pollen- und Honigwaben. Das Flugloch der Völker mit II-Königinnen war mit einem Königinnenabsperrgitter verschlossen, so dass kein Hochzeitsflug möglich war. Die NMKöniginnen wurden ebenfalls zufällig ausgewählt und unter ähnlichen Bedingungen gehalten wie die II-Königinnen mit dem Unterschied, dass das Flugloch für Hochzeitsflüge offen war. Die flüchtigen Komponenten von II- und NM-Königinnen wurden über eine SPME-Festphasenextraktion gesammelt und anschließend mit GC-MS-Methoden analysiert. 12 Substanzen konnten in mehr als $50 \%$ der II- und NM-Königinnen in zumindest einem Entwicklungsstadium nachgewiesen werden (Abb. 1). Von diesen 12 Substanzen waren 7 (darunter 2-Phenylethanol, n-Octanal, und n-Decanal) in höheren Konzentrationen bei unbegatteten als bei begatteten Königinnen vorhanden (Tab. I, Abb. 3). Die höhere Abgabe von jungfräulichen Königinnenduftstoffen könnte bei der Initiierung des Königinnenaustausches im Bienenvolk eine Rolle spielen. Im Gegensatz dazu wiesen eierlegende Königinnen höhere Konzentrationen von E- $\beta$-Ocimene als jungfräuliche Königinnen auf, was für die weitere Akzeptanz älterer Königinnen wichtig sein könnte. II- und NM-Königinnen zeigten während ihrer Entwicklung von jungfräulichen $\mathrm{zu}$ begatteten eierlegenden Königinnen ein ähnliches chemisches Profil (Beispiele für individuelle Profile siehe Abb. 2). II- und NM-Königinnen unterscheiden sich auch nicht hinsichtlich ihrer Annahmerate im Bienenvolk. Diese Ähnlichkeiten lassen vermuten, dass die Veränderungen im Duftstoffbouquet nach der Paarung und Eilage der Königinnen unabhängig von der Art der Besamung sind.

E- $\beta$-Ocimene / Honigbiene / Akzeptanz der Königin / n-Decanal / N-octanal / 2-Phenylethanol

\section{REFERENCES}

Becker M.M., Bruckner D., Crewe R. (2000) Behavioural response of drone honeybees, Apis mellifera carnica and Apis mellifera scutellata, to 
worker-produced pheromone compounds, J. Apic. Res. 39, 149-152.

Brian M.V. (1973) Queen recognition by brood-rearing workers of the ant Myrmica rubra L., Anim. Behav. 21, 691-698.

Cobey S.W. (2007) Comparison studies of instrumentally inseminated and naturally mated honey bee queens and factors affecting their performance, Apidologie 38, 390-410.

DeGrandi-Hoffman G., Gilley D., Hooper J. (2007) The influence of season and volatile compounds on the acceptance of introduced European honey bee (Apis mellifera L.) queens into European and Africanized colonies, Apidologie 38, 230-237.

Engels W., Rosenkranz P., Adler A., Taghizadeh T., Lübke G., Francke W. (1997) Mandibular gland volatiles and their ontogenetic patterns in queen honey bees, Apis mellifera carnica, J. Insect Physiol. 43, 307-313.

Gilley D.C., DeGrandi-Hoffman G., Hooper J.E. (2006) Volatile compounds emitted by live European honey bee (Apis mellifera L.) queens, J. Insect Physiol. 52, 520-527.

Harbo J.R., Harris J.W. (1999) Heritability in honey bees (Hymenoptera: Apidae) of characteristics associated with resistance to Varroa jacobsoni (Mesostigmata: Varroidae), J. Econ. Entomol. 92, 261-265.

Hoover S.E.R., Keeling C.I., Winston M.L., Slessor K.N. (2003) The effect of queen pheromones on worker honey bee ovary development, Naturwissenschaften 90, 477-480.

Jumean Z., Unruh T., Gries R., Gries G. (2005) Mastrus ridibundus parasitoids eavesdrop on cocoon-spinning codling moth, Cydia pomonella, larvae, Naturwissenschaften 92, 20-25.

Katzav-Gozansky T., Boulay R., Soroker V., Hefetz A. (2004) Queen-signal modulation of worker pheromonal composition in honeybees, Proc. R. Soc. London B 271, 2065-2069.

Keeling C.I., Slessor K.N., Higo H.A., Winston M.L. (2003) New components of the honey bee (Apis mellifera L.) queen retinue pheromone, Proc. Natl. Acad. Sci.100, 4486-4491.

Laidlaw Jr. H.H. (1979) Contemporary Queen Rearing, Dadant \& Sons, Hamilton, IL.

Laidlaw Jr. H.H. (1992) Production of queens and package bees, in: Graham J.M. (Ed.), The Hive and the Honey Bee, Dadant and Sons, Hamilton, IL, pp. 989-1042.

Mackensen O. (1947) Effect of carbon dioxide on initial oviposition of artificially inseminated and virgin queen bees, J. Econ. Entomol. 40, 344-349.

Naumann K., Winston M.L., Slessor K.N., Prestwich G.D., Latli B. (1992) Intra-nest transmission of aromatic honeybee queen mandibular gland pheromone components: movement as a unit, Can. Entomol. 124, 917-934.

Page R.E. Jr, Fondrk M.K. (1995) The effects of colony-level selection on the social organization of honey bee (Apis mellifera L.) colonies: colonylevel components of pollen hoarding, Behav. Ecol. Sociobiol. 36, 135-144.

Pankiw T., Winston M.L., Plettner E., Slessor K.N., Pettis J.S., Taylor O.R. (1996) Mandibular gland components of European and Africanized honey bee (Apis mellifera L.), J. Chem. Ecol. 22, 605615.

Pankiw T., Roman R., Sagili R.R., Zhu-Satzman K. (2004) Pheromone-modulated behavioral suites influence colony growth in the honey bee (Apis mellifera), Naturwissenschaften 91, 575-578.

Richard F.-J., Tarpy D.R., Grozinger C.M. (2007) Effects of insemination quantity on honey bee queen physiology, PLoS ONE 2(10), e980.

Rothenbuhler W.C. (1964) Behaviour genetics of nest cleaning in honey bees. I. Responses of four inbred lines to disease-killed brood, Anim. Behav. $12,578-583$.

Schneider S.S., DeGrandi-Hoffman G. (2002) The influence of worker behaviour and paternity on the development and emergence of honey bee queens, Insectes Soc. 49, 306-314.

Schneider S.S., DeGrandi-Hoffman G. (2003) The influence of paternity on virgin queen success in hybrid colonies of European and African honeybees, Anim. Behav. 65, 883-892.

Slessor K.N., Kaminski L., King G.G.S., Borden J.H., Winston M.L. (1988) Semiochemical basis of the retinue response to queen honey bees, Nature 332, 354-356.

Smith R.K., Spivak M., Taylor O.R., Bennett C., Smith M.L. (1993) Maturation of tergal gland alkene profiles in European honey bee queens, Apis mellifera L., J. Chem. Ecol. 19, 133-142.

Tarpy D.R., Gilley D.C. (2004) Group decision making during queen production in colonies of highly eusocial bees, Apidologie 35, 207-216.

Torto B., Suazo A., Alborn H., Tumlinson J.H., Teal P.E.A. (2005) Responses of the small hive beetle (Aethina tumida) to a blend of chemicals identified from honeybee (Apis mellifera) volatiles, Apidologie 36, 523-532.

Vargo E.L. (1997) Poison gland of queen fire ants (Solenopsis invicta) is the source of a primer pheromone, Naturwissenschaften 84, 507-510.

Vargo E.L. (1999) Reproductive development and ontogeny of queen pheromone production in the fire ant Solenopsis invicta, Physiol. Entomol. 24, 370376.

Vogel A.I., Tatchell A.R., Furnis B.S., Hannaford A.J., Smith P.W.J. (1989) Vogel's Textbook of Practical Organic Chemistry (5th ed.), John Wiley \& Sons, Inc., New York.

Wossler T.C., Jones G.E., Allsopp M.H., Hepburn R. (2006) Virgin queen mandibular gland signals of Apis mellifera capensis change with age and affect honeybee worker responses, J. Chem. Ecol. 32, 1043-1056. 